\title{
Combined Sewer Overflows (CSOs) Impact on Water Quality and Environmental Ecosystem in the Harlem River
}

\author{
Jingyu Wang1,2 \\ ${ }^{1}$ Chemistry and Chemical Technology Department, Bronx Community College, New York, USA \\ ${ }^{2}$ Earth, Environmental and Geospatial Sciences Department, Lehman College, New York, USA \\ Email: jingyu.wang@bcc.cuny.edu, jingyu.wang@lehman.cuny.edu
}

Received 19 August 2014; revised 16 September 2014; accepted 12 October 2014

Copyright (C) 2014 by author and Scientific Research Publishing Inc.

This work is licensed under the Creative Commons Attribution International License (CC BY). http://creativecommons.org/licenses/by/4.0/

c) (i) Open Access

\section{Abstract}

The Harlem River, a 9.3-mile channel that flows from the Hudson River to the East River, has experienced decades of industrial abuse and remains gritty and industrial. During heavy rains, the pipes discharge raw sewage into the river through combined sewer overflows (CSOs) that can contain bacteria and cause illness. Water samples were collected from CSO discharge point and several adjacent sites along the river in the Bronx side close to River Park Towers at Richman Plaza and Manhattan side at Wards Island. Nutrients, bacteria, polychlorinated biphenyls (PCBs), and fish consumption safety have been analyzed. Results showed that phosphorus, ammonia concentration as well as fecal coliform, E.Coli, enterococcus levels increased significantly during heavy rainstorms. Ammonia concentration was up to $2.725 \mathrm{mg} / \mathrm{L}$ during tropical storm Arthur on July 2, 2014 and rainstorm in May 2013, and soluble reactive phosphorus (SRP) or orthophosphate was up to $0.197 \mathrm{mg} / \mathrm{L}$ during heavy thunderstorm in April 2011; both nutrients were exceeded EPA regulation for ammonia $(0.23 \mathrm{mg} / \mathrm{L})$ and phosphate $(0.033 \mathrm{mg} / \mathrm{L})$ for New York City (NYC) waters. The colonies of fecal coliform were more than 5 million MPN/100ml (most probable number per $100 \mathrm{ml}$ ) during tropical storm Arthur in July 2014 and heavy rainstorm in April 2014, and fecal coliform was more than 10,000 MPN/100ml during storm in July and November 2013; E.Coli reached more than 5000 MPN/100ml during tropical storm Arthur and storm in May 2013; enterococcus reached more than 10,000 MPN/100ml during tropical storm Arthur and heavy rainstorm in April 2014. These bacteria (pathogen) levels in the Harlem River were significantly higher than EPA standards (fecal coliform: 200 MPN/100ml, E.Coli: 126 MPN/100ml, enterococcus: $104 \mathrm{MPN} / 100 \mathrm{ml}$ ), especially during rainstorm/tropical storm. Of particular significance, nutrients and bacteria were analyzed before and after Hurricane Sandy devastated NYC in late October 2012; results determined that bacteria and ammonia concentrations increased after this monumental storm, elucidating the environmental impact of large storm events. PCB 11 (3,3'-dichlorobiphenyl, 
$\mathrm{C}_{12} \mathrm{H}_{8} \mathrm{C}_{12}$ ), the high molecular weight (MW), an indicator of raw sewer and storm water runoff in the NYC harbor waters, is the major polychlorinated biphenyls (PCBs) in the Harlem River. PCBs are carcinogenic, which could bioaccumulate via food chain from fish and seafood, endangering public health. Oyster farming has been used to purify water and improve water quality in the river. CSOs and storm water runoff have degraded water quality and been threatening environmental ecosystem and public health. This research will help local communities understand CSO impact on nutrients, bacteria, PCBs contamination and fish consumption safety, and make contributions on CSOs reduction as well as improve water quality and environmental ecosystem in the Harlem River.

\section{Keywords}

CSOs, Ammonia, Phosphate, Fecal Coliform, E.Coli, Enterococcus, PCBs, Fish Consumption Safety

\section{Introduction}

Combined sewer overflow (CSO) water is a mixture of urban runoff and municipal wastewater; is discharged into rivers and canals during heavy rainfall; releases dissolved contaminants, particulate organic matter loads, oxygen consumption, bacteria and viruses, causing fish death and health risks [1] [2]. CSO under wet weather and permanent dry weather impacts the river quality spatially and temporally [1]. In frequent-rainfall regions, CSO causes contaminations frequently, which was weather and climate dependent [3]. In dry weather, a combined sewerage system theoretically only collects municipal waste [3]. In wet weather, wastewater is mixed with urban runoff water, and sometimes the sewer systems could not transport all the wastewater to reach the waste water treatment plant (WWTP) or the wastewater capacity exceeds the WWTP treatment capacity. In this situation, CSOs occur, resulting in untreated sewer (raw sewer) discharge into urban river systems, such as the sewer discharge into the Harlem River in the Bronx side during storm [4]. CSOs and sanitary sewers are often a significant source of unsafe levels of pathogens in urban areas that endangers swimming, fishing and other recreation uses [5].

CSOs regularly caused strong oxygen depletion in the river, endangering the fish population and water quality [1] [6]. CSO impacts the river ecology and water quality; high load of organic matter (OM) brought by untreated wastewater causes oxygen depletion; the reduction of photosynthetic primary production increases turbidity; plus metal and organic pollutants' concentrations increase; nutrient levels increase and bacteria increase [4]. Total SS, biological oxygen demand $\left(\mathrm{BOD}_{5}\right), \mathrm{NH}_{4}$ or total Kjedal nitrogen (TKN), nitrates and total phosphorus concentrations were considered as basic parameters of CSOs test [7]. The CSOs effects on contaminants load include: oxygen demand (BOD, COD and $\mathrm{NH}_{4}^{+}$), nutrients $(\mathrm{N}$ and $\mathrm{P})$, toxic substances $\left(\mathrm{NH}_{3}\right.$, heavy metals, microcontaminants), hygiene (fecal coliform, E.Coli, enterococcus bacteria), and physical parameters (temperature, suspended solids, flow, EC, pH, DO, redox etc.) [3]. When the CSO exceeded the capacity of waste water treatment plant, the discharge receiving river may be contaminated severely [3]. Industry, agriculture and domestic sewage are three major sources of phosphorus pollution in aquatic environment [8] [9]. Some of the high nutrient levels (nitrogen and phosphorus) were found in downstream urban rivers close to WWTP facility [10]. Toxic contamination, pathogens and wetland loss are primary environmental concerns in the NY/NJ Harbor system. Untreated sewage particularly contributed by CSOs during rains has been threatening water quality in NY/NJ Harbor [11].

The combined sewage system in NYC carries both storm water and sanitary wastewater in the same pipe to WWTP in dry weather, where it is treated before being discharged into local waterways. During wet weather conditions, when there is heavy rainfall, water volume exceeds the pipe capacity, and the excess is discharged into rivers and streams directly without treatment. This is called CSOs as mentioned above. Over $90 \%$ of the pollution in NYC's waterways is from this runoff [2] [12]. The CSOs can contaminate water and degrade water quality; can carry bacteria and viruses; and cause diseases [2]. During wet weather, discharge points along the Harlem River may discharge rainwater mixed with untreated sewage that contains bacteria and can cause illness. There is a warning sign about the safety at the Wet Weather Discharge Point: "This outfall may discharge rainwater mixed with untreated sewage during or following rainfall and can contain bacteria that can cause illness"; 
"If you see a discharge during dry weather, please call 311 or contact NYS DEC office". In summer, sewer overflow discharges a large amount of nutrients, including P, N, ammonia, pathogens (fecal coliform, E.Coli, and enterococcus) and other pollutants into the river. These pollutants can stay in the river for nearly half month before flowing into the Atlantic Ocean.

Determining the nutrients and pollutants level is important to help reduce water contamination and improve water quality in the Harlem River. Phytoremediation with water hyacinth, a floating aquatic plant, native to tropical America, has been used to remove total phosphorous (TP) and ammonia nitrogen $\left(\mathrm{NH}_{3}-\mathrm{N}\right)$ [9] [13]. However, water hyacinth had been planted in the Harlem River and Harlem Meer (lake) in Central Park, which could not be able to survive or remove nutrients due to different hydro-climatic conditions. Oysters farming had been used to filter the NYC river water; they absorbed the contaminants and improved water quality in the Harlem River and the Bronx River. The Bronx oysters have the ability to filter pollutants and anchor a marine ecosystem with their craggy reefs [14].

Polychlorinated biphenyls (PCBs) have historically been a pollution problem in the Hudson River and the Harlem River-tributary of the Hudson River. Sources of PCBs in the Harlem River are from the upper Hudson River general electric (GE) plants located at Fort Edward and Hudson Falls [15]-[17]; as well as from Harlem River local sources including storm water runoff, CSOs, and wastewater effluents [18]. PCBs from the upper Hudson River are dominated by lower molecular weight (MW) congeners including low MW Aroclor 1254 by GE as well as dechlorination of PCBs in the sediments [18]. In the Harlem River and NY/NJ Harbor, high MW PCBs sources are dominated by storm water runoff and CSOs mostly PCB 11 that is a non-Aroclor congener and is an indicator of storm water, CSOs and wastewater [18]-[20]. PCBs affect human health through the food chain or by individual exposure, such as swimming. PCBs that are bioaccumulated through the food chain from fish and seafood, such as striped bass, American eel etc. can cause cancer in animals. PCBs also can cause non-cancer health effects such as reduced ability to fight infections, low birth weights, and learning problems [21].

Striped bass caught in the Hudson River had been banned from commercial in 1970's because PCB's concentration is more than EPA regulated level of 2 ppm (parts per million). After 1980's, striped bass was back to commercial after PCB levels lower than 2 ppm [22]. GE was fined by EPA for 6 million dollars for dredging out the polluted sediments [23], and the project has been on-going since 2006 [24]. The New York State Department of Health (NYS DOH) 2002-2003 Health Advisories for Chemicals in Sport Fish and Game listed fish consumption advisories for the Harlem River, especially for women under 50 years old and children under 15 years old (Table 1) [25]. The major concern was for fish containing PCBs, including the American eel, striped bass, and blue fish [26].

The Harlem River, a tributary of the Hudson River, receives pollutants from the Hudson River; therefore the pollutants including mercury and PCBs flow into the Harlem River. Mercury, PCBs, as well as low levels of radioactive material have historically been found in the Harlem River system. PCBs contamination of fish is a primary concern for both the Hudson River and Harlem River water bodies [27]. Pollutants from the East River flow into the Harlem River, as well [28]. Even though water quality parameters do not exceed NYC DEP standards, the Harlem River received substantial pollutants from urban runoff, including storm water runoff and CSOs. There are around 50 Harlem River CSOs sources, which are greater than those of the Hudson and the Bronx Rivers [29]. Water in the Harlem River is turbid because high suspended solid content and high concentrations

Table 1. Advice of fish consumption caught in the Harlem River [25].

\begin{tabular}{cccc}
\hline fish & $\begin{array}{c}\text { Men over } 15 \text { and } \\
\text { Women over 50 }\end{array}$ & $\begin{array}{c}\text { Women under 50 \& } \\
\text { Children under 15 }\end{array}$ & Chemicals of Concern \\
\hline Blue Crab Meat & $\begin{array}{c}\text { Up to } 4 \text { meals/month } \\
\text { (6 Crabs per Meal) }\end{array}$ & Don't Eat & PCBs, Cadmium \\
$\begin{array}{c}\text { Crab or Lobster Tomalley (Hepatopancreas, } \\
\text { Mustard) and Cooking Liquid }\end{array}$ & Don't Eat \\
$\begin{array}{c}\text { Channel Catfish, Gizzard Shad, White Catfish } \\
\text { Atlantic Needlefish, Bluefish, Carp, Goldfish, } \\
\text { Rainbow Smelt, Striped Bass, White Perch }\end{array}$ & Don't Eat & Don't Eat & PCBs, Cadmium, Dioxin \\
All Other Fish & Up to 1 meal/month & Don't Eat & PCBs \\
\hline
\end{tabular}


of nutrients that potentially lead to nutrient enrichment [30].

The Federal Clean Water Act limits the amount of ammonia that can be discharged into wastewater treatment plant effluents to $1 \mathrm{mg} / \mathrm{L}$. Many municipalities use bacteria to remove ammonia from water by nitrification/denitrification. Some municipalities retain breakpoint chlorination to remove ammonia from wastewater effluents [31]. The US EPA suggested a criterion concentration of $P$ of maximum of $0.015 \mathrm{mg} / \mathrm{L}$ in reservoirs [32]. The national background P concentration was $0.042 \mathrm{mg} / \mathrm{L}$ [10]. The highest TP concentrations were in streams in urban and agricultural areas (in US), and the median concentration $(0.25 \mathrm{mg} / \mathrm{L}$ or $250 \mu \mathrm{g} / \mathrm{L})$ was around 6 times greater than background concentrations $(0.042 \mathrm{mg} / \mathrm{L}$ or $42 \mu \mathrm{g} / \mathrm{L})$. In urban area, P sources were runoff from golf courses, residential lawns, construction sites, sewage overflow (treated wastewater effluent), and septic-system drainage. In agricultural area, P sources were associated with fertilizers and manure intensive applications [10]. EPA's criterion of nutrient for ecoregion of $\mathrm{P}$ is $0.033 \mathrm{mg} / \mathrm{L}$ or $33 \mu \mathrm{g} / \mathrm{L}$ [33]. US EPA ammonia criterion is 0.23 $\mathrm{mg} / \mathrm{L}(230 \mu \mathrm{g} / \mathrm{L})$ [34]. NYS DEC suggested using EPA's chronic value of DO-4.8 mg/L for NYC waters. EPA recommends that DO for Class I marine water is never less than $4.0 \mathrm{mg} / \mathrm{L}$; the aquatic life survival DO value is never less than $2.3 \mathrm{mg} / \mathrm{L}$ [34]. EPA standards of bacteria levels in NYC waters: fecal coliform < $200 \mathrm{MPN} /$ 100ml (most probable number per $100 \mathrm{ml}$ ), E.Coli < $126 \mathrm{MPN} / 100 \mathrm{ml}$, and enterococcus < $104 \mathrm{MPN} / 100 \mathrm{ml}$ [35]. EPA standard of turbidity for NY/NJ waters is 0.25 - 5.25 FAU/NTU [33] [36].

The Harlem River has been used as a major resource for water recreation throughout its history [29]. Currently there is limited accessibility to the Harlem River for community enjoyment, and the Harlem River watershed has been highly urbanized. Water quality has been degraded by CSOs as point-source pollution and storm water runoff and activates from the Hudson/East River as nonpoint sources of pollution [28]. Untreated sewage contributes to decrease in usability and water quality, as increased fecal coliform and enterococci levels, decreased dissolved oxygen and increased nutrient levels. There are basic water quality parameters and enterococcus levels on Riverkeeper website [37] [38]; however the data are limited and some pollutants levels (such as turbidity and enterococcus) were underestimated. Nutrient and bacteria levels in the Harlem River on USGS website [28] were underestimated. This research has aimed to provide more updated and accurate bacteria, supplement nutrients and water quality data; provide solid references and comparison to existed data to EPA, NYC DEP, NYC DEP, USGS, Urban Divers Ecology Center (UDEC), Bronx Council for Environmental Quality (BCEQ), Bronx River Alliance, and Riverkeepers; help improve water quality, community accessibility, water recreation and ecology restoration of the Harlem River. This research has been conducted since 2011 to present: collected water samples and analyzed EC, pH, ammonia, phosphate, turbidity, fecal coliform, E.Coli, enterococcus and PCBs; estimated the levels if exceeded EPA regulated concentration in NYC waters; determined CSOs impact on water contamination; kept communities aware of fish consumption safety.

\section{Material and Methods}

\subsection{Study Area}

The Harlem River (Figure 1), a 9.3-mile channel that flows from the Hudson River to the East River, has been experienced decades of industrial abuse and remains gritty and industrial. "In the Bronx side, major highways and train tracks cut the public off from the water on the Bronx side, and the pipes that discharge raw sewage during heavy rains dot both shores [39].” The Harlem River is classified by New York State Department of Environmental Conservation (NYS DEC) as a Class I saline surface water for secondary contact recreation and fishing [30], swimming as primary contact is not safe in the river [28].

The Harlem River is part of Hudson River estuary system. It is a navigable tidal straight that divides the island of Manhattan from the Bronx. The Harlem River flows between the Hudson River and the East River, separating the boroughs of Manhattan and the Bronx [40]. It connects two larger water bodies, stretching from the Hudson River to the intersection of the East River at Randall's Island, at approximately 125th Street in Manhat$\tan [40]$. Currents fluctuate dramatically in the Harlem River because of the ebb and flow of the tides. Tides affect pollutants, silt, and suspended sediments transported in the water. Tides make it particularly difficult to navigate in the northern portion of the waterway in the Harlem River [40]. Wards Island WWTP is the only WWTP serves the Harlem River. Precipitation, increased water use and WWTP failure caused CSOs discharge into the Harlem River [28].

Over the past century, the Harlem River watershed has become highly urbanized with 90 percent of the waterway constrained by infrastructure, and there is limited accessibility to the Harlem River for community [28]. 


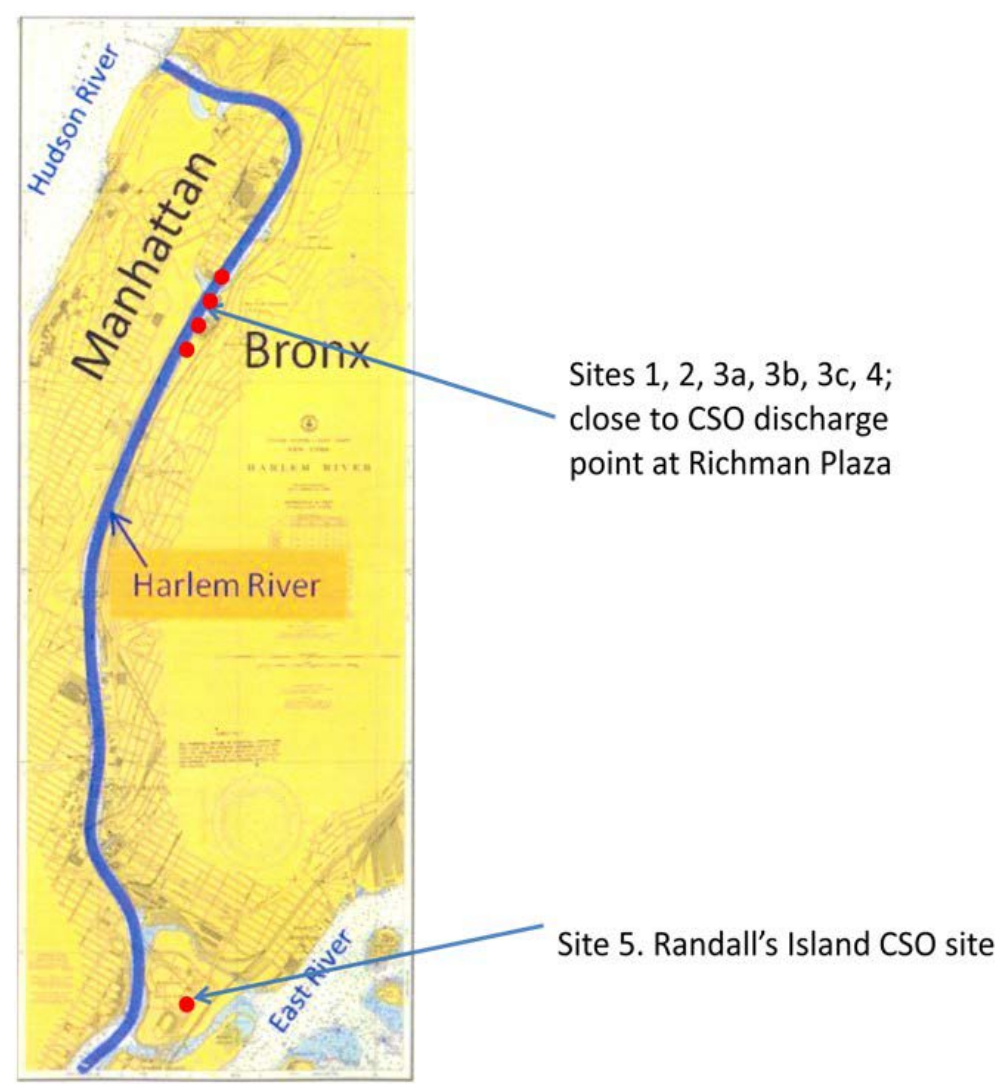

Figure 1. Harlem River study area and sampling sites (map source: USGS, 2012).

The Harlem River became highly industrialized as urban sprawl continued and local economy grew. Historically swimming, boating and fishing were activities of the Harlem River. South Bronx Officials are trying to turn an industrial area between $149^{\text {th }}$ and $138^{\text {th }}$ Streets into a waterfront district, making both sides of the river accessible to the public [41]. During rainstorm, there are more than 50 CSOs that discharge untreated sewage and runoff from impervious surface to the Harlem River [28]. NYC DEP and NYS DEC made effort to divert some of the rainwater from reaching CSOs in order to reduce the untreated sewage load to the local waterway, which is aim to help ecological restoration of the Harlem River [28]. CSO discharge of untreated sewage during precipitation events contributes pollutants that degrade water quality and impact aquatic life and enjoyment by residents. Tidal current carried pollutants from the Hudson River and East River and effluent from sewage retreatment plant [28].

\subsection{CSOs Water Sampling}

Water samples were collected from the CSO discharge point located at River Park Towers in Richman Plaza beside Roberto Clemente State Park, which is the major sampling site. Other sites are: beside Harlem River Ecology Center (HREC), CSOs tank, CSOs overflow, beach below the High Bridge and CSO discharge point at Randal's Island (Table 2). Most sites other than Randal's Island site are located in the Bronx section of the River. Water samples were transported to Bronx Community College (BCC) Chemistry Laboratory and Lehman College Environmental Laboratory and analyzed EC, $\mathrm{pH}$, ammonia, turbidity and bacteria immediately; stored at $4^{\circ} \mathrm{C}$ for further experimental analysis.

\subsection{Bacteria Analysis}

Water samples were filtered through $0.45 \mu \mathrm{m}$ sterilized membrane, then transfer the membrane to the selective agar plates for fecal coliform, E.Coli, and enterococcus; incubate at $37^{\circ} \mathrm{C}$ for $24 \mathrm{~h}$ and count the colonies as MPN/100ml. 
Table 2. Water sampling sites’ locations and coordinates in the Harlem River.

\begin{tabular}{ccccc}
\hline Site\# & Name & Location & Latitude & Longitude \\
\hline 1 & HREC & Water front beside HREC office at 10 Richman Plaza & $40^{\circ} 51^{\prime} 04.62^{\prime \prime} \mathrm{N}$ & $73^{\circ} 55^{\prime} 26.13^{\prime \prime} \mathrm{W}$ \\
2 & Beside HREC & Below the fence, water front beside UDEC office at 10 Richman Plaza & $40^{\circ} 51^{\prime} 04.38^{\prime \prime} \mathrm{N}$ & $73^{\circ} 55^{\prime} 26.29^{\prime \prime} \mathrm{W}$ \\
3 & CSO & CSO wet weather discharge point & $40^{\circ} 51^{\prime} 02.42^{\prime \prime} \mathrm{N}$ & $73^{\circ} 55^{\prime} 27.00^{\prime \prime} \mathrm{W}$ \\
3a & CSO surface & Beside CSO discharge site pipes, surface water site & $40^{\circ} 51^{\prime} 02.42^{\prime \prime} \mathrm{N}$ & $73^{\circ} 55^{\prime} 27.00^{\prime \prime} \mathrm{W}$ \\
3b & CSO downstream & 50 yards south downstream of CSO discharge site & & \\
$3 \mathrm{c}$ & CSO tank & The tank of CSOs discharged to the pipes & $40^{\circ} 51^{\prime} 02.42^{\prime \prime} \mathrm{N}$ & $73^{\circ} 55^{\prime} 27.00^{\prime \prime} \mathrm{W}$ \\
4 & Beach & Beach below high bridge & $40^{\circ} 50^{\prime} 32.50^{\prime \prime} \mathrm{N}$ & $73^{\circ} 55^{\prime} 46.18^{\prime \prime} \mathrm{W}$ \\
5 & Randall's Island site 1 & $40^{\circ} 48^{\prime} 06.95^{\prime \prime} \mathrm{N}$ & $73^{\circ} 55^{\prime} 31.98^{\prime \prime} \mathrm{W}$ \\
Hudson & Hudson River & Close to CSO discharged point & $40^{\circ} 49^{\prime} 11.75^{\prime \prime} \mathrm{N}$ & $73^{\circ} 57^{\prime} 37.36^{\prime \prime} \mathrm{W}$ \\
\hline
\end{tabular}

Harlem River: sites 1, 2, 3, 3a, 3b, 3c, 4 and 5. Hudson River: North River WWTP raw sewer spill site at $125^{\text {th }}$ St.

\subsection{Ammonia}

Filtered water samples were analyzed by Nessler reagent method for ammonia $\left(\mathrm{NH}_{3}-\mathrm{N}\right)$, using the HACH Program \#25 on the HACH 4000 spectrophotometer [31] [42].

\subsection{Phosphate (Soluble Reactive Phosphorus)}

Filtered water samples were analyzed automated ascorbic acid method [43], by Shimazu UV-2501PC probe spectrophotometer at wavelength $880 \mathrm{~nm}$.

\subsection{Turbidity}

Turbidity was measured by HACH 4000 spectrophotometer [42], recorded as FAU. Use 10 ml deionized distilled water as blank and zero, then place $10 \mathrm{ml}$ water sample into the glass cell and record turbidity data [31] [42].

\subsection{PCBs}

The water samples were extracted by methylene chloride (dichloromethane-DCM): 100 ml water sample mixed with $100 \mathrm{ml}$ DCM, shaking well in a separation funnel, get DCM extraction with a beaker with sodium sulfate $\left(\mathrm{Na}_{2} \mathrm{SO}_{4}\right.$ as drying agent), then concentrate the extraction in a rotavapor to $5 \mathrm{ml}$, filter with pipette (cotton and silica gel), reconstitute with isooctane to keep the same matrix as the standard of PCB 11: 3,3'-dichlorobiphenyl (BZ\#11) $(100 \mu \mathrm{g} / \mathrm{ml})$ and matrix is isooctane (2,2,4-trimethylpentane). Then analyze by high resolution gas chromatography/mass spectrometry (HRGC/MS) at BCC Chemistry Department [44] [45]. In order to get strong signal, water sample was concentrated before extraction, and spike with non-Aroclor congener PCB 11/Aroclor $1242 / 1254$ standards.

\section{Results and Discussion}

\subsection{EC, $\mathrm{pH}, \mathrm{DO}$}

$\mathrm{EC}$ and $\mathrm{pH}$ is considerable stable among different sites in different weather conditions (Table 3). Average $\mathrm{pH}$ was 7.22 in water samples collected in 2014, 7.26 in 2013, and 7.52 in 2011, which were lower than average pH in the Bronx River 7.8 for water samples collected in 2006 and 2007 [46]-[48]. Average EC for water samples collected in the Harlem River in 2011 and 2013 was $2271 \mu \mathrm{s} / \mathrm{cm}$, which was significantly higher than EC in the Bronx River freshwater section (756 $\mu \mathrm{s} / \mathrm{cm}$ in 2006; $741 \mu \mathrm{s} / \mathrm{cm}$ in 2007); which was lower than the EC in the Bronx River saline estuary sites at Sound View Park (34,900 $\mu \mathrm{s} / \mathrm{cm}$ in 2006; 31,600 $\mu \mathrm{s} / \mathrm{cm}$ in 2007) [46]-[48]. The EC maximum in 2014 was 1794 ps/cm on July 28, 2014; however during heavy rainstorm on April 302014 EC decreased to $19.22 \mu \mathrm{s} / \mathrm{cm}$ and dilution could cause the low EC (EC and pH were not available in some of the data in 2014 due to instrument usage limitation). Harlem River was a mixing with fresh and saline water, therefore the EC was higher than freshwater, and lower than estuary in the Bronx River. The New York/New Jersey (NY/NJ) Harbor is rated good for DO concentrations, with $62 \%$ of the estuary are rated good for this component 
Table 3. Water quality data of the Harlem River from 2011-2014.

\begin{tabular}{|c|c|c|c|c|c|c|c|}
\hline Date & Weather & Site & $\mathrm{pH}$ & $\mathrm{EC} \mu \mathrm{s} / \mathrm{cm}$ & Fecal coliform & E.Coli & Enterococcus \\
\hline $4 / 22 / 14$ & Afternoon showers & 3a & 6.63 & 825.5 & 2500 & 10 & 54 \\
\hline $4 / 30 / 14$ & Heavy rain & 3 & 7.06 & 19.22 & 5 million & 500 & 10,000 \\
\hline $7 / 2 / 14$ & Tropical storm Arthur & 3 & & & $>5$ million & $>5000$ & 10,000 \\
\hline $7 / 14 / 14$ & Rainstorm afternoon & 3a & & & millions & $1000-2000$ & $2000-2500$ \\
\hline $7 / 24 / 14$ & Rain night before & 3a & & & 1100 & 136 & 335 \\
\hline $7 / 29 / 14$ & Sunny & За & 7.67 & 1797 & $80-100$ & 44 & 160 \\
\hline 3/30/13 & Cloudy storm & $3 c$ & 7.55 & 1878 & & & \\
\hline $5 / 1 / 13$ & Sunny & $3 c$ & 7.40 & 3070 & 400 & 18 & 35 \\
\hline $5 / 8 / 13$ & Rainstorm & 3c & 7.23 & & millions & $>5000$ & $>500$ \\
\hline $5 / 9 / 13$ & Rainstorm & 3c & 7.28 & & $<$ millions & $<5000$ & $<500$ \\
\hline $5 / 23 / 13$ & Thunderstorm & 3c & 7.02 & & $>5000$ & $>2000$ & $>2000$ \\
\hline $7 / 8 / 13$ & Sunny & 5. RI1 & 7.10 & 1942 & $>5$ millions & $>5000$ & 100 \\
\hline 7/12/13 & Showers & 3c & 7.02 & 1644 & 10,000 & 300 & 820 \\
\hline $10 / 4 / 13$ & Drizzle & $3 c$ & 7.28 & & 200 & 5 & 42 \\
\hline 10/7/13 & Showers & 3c & 7.29 & & 7500 & 220 & 600 \\
\hline $11 / 1 / 13$ & Rain & 3c & 7.41 & & $>10,000$ & 500 & $>5000$ \\
\hline 3/10/11 & Rain, windy & 1 & 7.5 & & 100 & 20 & \\
\hline 3/17/11 & Sunny & 2 & 7.7 & & $>1000$ & 100 & 2 \\
\hline $3 / 24 / 11$ & Day after rain & 1 & 7.5 & 2820 & $800-1000$ & 0 & 6 \\
\hline $4 / 7 / 11$ & Rain morning & 2 & & & & & \\
\hline $4 / 7 / 11$ & Rain morning & $3 c$ & & & $>2000$ & $>1000$ & 800 \\
\hline $4 / 28 / 11$ & Thunderstorm & 3 & & & millions & thousands & 0 \\
\hline $4 / 28 / 11$ & Thunderstorm & 3a & & & thousands & hundreds & 0 \\
\hline 4/28/11 & Thunderstorm & $3 b$ & & & & & \\
\hline $5 / 5 / 11$ & Sun mix clouds & 3a & & & & & \\
\hline $5 / 5 / 11$ & Sun mix clouds & 4 & 6.7 & & hundreds & 100 & 20 \\
\hline $5 / 12 / 11$ & Cloudy & За & & & & & \\
\hline $5 / 12 / 11$ & Cloudy & 4 & 7.52 & & & & \\
\hline 7/13/11 & & 3a & & & & & \\
\hline 7/13/11 & & 4 & & & & & \\
\hline $7 / 25 / 11$ & & 3a & & & & & hundreds \\
\hline $7 / 25 / 11$ & & $3 c$ & & & >thousands & hundreds & thousands \\
\hline 7/25/11 & & H-NR & & & & & thousands \\
\hline 9/28/11 & & 3a & & & & & \\
\hline 7/18/12 & & 3a & & & & & \\
\hline 9/18/13 & & 3a & & & & & \\
\hline $10 / 24 / 12$ & Before Sandy & За & & & & 100 & \\
\hline $11 / 1 / 12$ & After Sandy & 3a & 7.33 & & & $>100$ & \\
\hline 11/8/12 & After Nor'easter & 3a & & & & & \\
\hline
\end{tabular}

5. RI1: Randall's Island site 1; H-NR: Hudson River site close to North River WWTP raw sewer spill at $125^{\text {th }}$ St.

indicator and none of the area rated poor [11]. The DO ranged from $4.65(59 \%)$ to $7.52(66.9 \%) \mathrm{mg} / \mathrm{L}$ in 2011; average DO in the Harlem River was $6.21 \mathrm{mg} / \mathrm{L}$ or 63.6\% (water collected in 2011; no DO data in 2012,2013 and part of the data in 2014 due to funding limitation and instrument shortage); which has similar range compared to USGS data for surface water 2 to $9 \mathrm{mg} / \mathrm{L}$ in a 5-year increments and average is higher than USGS data $4 \mathrm{mg} / \mathrm{L}$ [28]. However, during tropical storm Arthur on 7/2/2014, the DO was $4.0 \mathrm{mg} / \mathrm{L}$ (49\%) at beginning of the heavy thunderstorm and then dropped down to $2.9 \mathrm{mg} / \mathrm{L}$ (35\%) as the tropical storm getting heavier. It indi- 
cated that DO in the CSOs decreased significantly during heavy tropical storm, which was lower than USGS average DO of $4 \mathrm{mg} / \mathrm{L} \mathrm{[28]} \mathrm{and} \mathrm{EPA} \mathrm{standard} \mathrm{that} \mathrm{DO} \mathrm{for} \mathrm{Class} \mathrm{I} \mathrm{marine} \mathrm{water} \mathrm{is} \mathrm{never-less-than} 4.0 \mathrm{mg} / \mathrm{L}$ [34]. It was lower than DO minimum $48 \%$ at Harlem River-Washington Bridge data [38].

\subsection{Bacteria-Fecal Coliform, E.Coli, and Enterococcus}

Fecal coliform, E.Coli, enterococcus levels increased significantly during heavy rains (Table 3). Fecal coliform was more than 5 million MPN/100ml in CSOs at CSO discharge point (site 3) during tropical storm Arthur on July 2, 2014. It reached 5 million MPN/100ml during heavy rainstorm on April 30, 2014 at site 3 as well as on July 8, 2013 at Randall's Island site 1 (close to CSO discharge point). Fecal coliform reaches millions (uncountable colonies) MPN/100ml during rain storm on July 14, 2014; May 8 - 9, 2013 at site 3a (surface water close to the CSO discharge point), and April 28, 2011 at site 3 CSO discharge point; more than 10,000 MPN/100ml in heavy rain in July and November 2013; far exceeded EPA standard of 200 MPN/100ml. Summer average fecal coliform ranged from 40 to $2500 \mathrm{MPN} / 100 \mathrm{ml}$ among the data 1909 to 2009 [28], this research indicated that much higher level of fecal coliform in the Harlem River during spring and summer especially during heavy rainstorms at CSO discharge points along the river.

E.Coli was more than thousands, 5000, 1000, $500 \mathrm{MPN} / 100 \mathrm{ml}$ during heavy rains as well (EPA standard is 126/100ml). E.Coli was more than 5000 MPN/100ml duringtropical storm Arthur on July 2, 2014 and rainstorm on May 8, 2013, and reached thousands MPN/100ml on April 28, 2011 during heavy thunderstorm. E.Coli appeared high level $>5000$ MPN/100ml on July 8, 2013, a dry day at Randall's Island site 1 where close to CSO discharge point and Wards Island WWTP. There was an increase of pathogens (used no-selective plate, could not distinguish bacteria type) after Hurricane Sandy (>100 MPN/100ml) compared to before Sandy (100 MPN/100ml).

Enterococcus, an indicator of raw sewer, reached 10,000 MPN/100ml during tropical storm Arthur on July 2, 2014 and heavy rainstorm on April 30, 2014; which was nearly twice as the maximum of Riverkeeper's data of 5635 MPN/100ml on 7/14/2008 at Harlem River-Willis Ave. Bridge [38] (Table 4). Enterococcus maximum levels in 2014 on Riverkeeper's website was 148 MPN/100ml on 5/12/2014 at Harlem River-Washington Bridge station, and 109 MPN/100ml on 5/12/2014 at Harlem River-Willis Ave. Bridge station (Table 4). Riverkeeper published data was short of tropical storm and heavy rainstorm data in 2014 [38], and it could underestimate the maximum enterococcus levels in the Harlem River. Enterococcus reached $5000 \mathrm{MPN} / 100 \mathrm{ml}$ during heavy rainstorm in Nov 1, 2013; >2000 MPN/100ml during thunderstorm on May 23, 2013; reached 800 MPN/100ml on April 7, 2011 during rains, and 500 MPN/100ml during storm on May 8 - 9, 2013. Enterococcus could reach significantly high levels during heavy tropical storm/rainstorms. CSOs discharged raw sewer during rainstorm resulted in increased enterococcus level exceeded EPA standard of $104 \mathrm{MPN} / 100 \mathrm{ml}$ [35], which might cause illness threatening public health and environmental ecosystem in the river. Compared to river keeper's count in 2013 on their website (Table 3 and Table 4), the maximum of Harlem River-Willis Ave. Bridge was $173 \mathrm{MPN} / 100 \mathrm{ml}$ on 8/14/13 and the maximum of Harlem River-Washington Bridge was 1670 MPN/100ml on 08/14/2013, both were unacceptable, exceeded the sample thresholds (111 MPN/100ml) [37] [38]. Enterococcus count from CSOs discharge point research site close to River Park Towers at Richman Plaza, close by Roberto Clemente State Park, maximum was $>5000$ MPN/100ml on 11/1/2013, significantly higher than Willis Ave and Washington Bridge data from Riverkeeper record in 2013 and similar to historical high record in 2008 of 5635 MPN/100ml at Harlem River-Willis Ave. Bridge and higher than record in 2013 of 1670 MPN/100ml at Harlem River-Washington Bridge (Table 3 and Table 4) [37] [38]. Enterococcus level was more than 2000 MPN/100ml on May 23, 2013 during heavy thunderstorm in the Harlem River, which was more than river keeper's data of 1670 MPN/100ml on August 14, 2013 during rainstorm at Harlem River-Washington Bridge. Enterococcus level reached $820 \mathrm{MPN} / 100 \mathrm{ml}$ in rainstorm on July 12, 2013; which was lower than river keeper's data in summer storm on August 14, 2013 (1670 MPN/100ml) at Harlem River-Washington Bridge.

In 2011, enterococcus reached thousands MPN/100ml on 7/25/2011, which was more than enterococcus in the Hudson River. This collection was five days after a catastrophic fire that destroyed one wastewater tank of North River wastewater treatment plant (WWTP) resulting in raw sewer spilled 125 million gallons per day to the Hudson River. Enterococcus level in the Harlem River (>thousands MPN/100ml) was higher than this raw sewer spill site on the Hudson (thousands MPN/100ml). This maximum reading in 2011 that more than thousands MPN/100ml was significantly higher than Riverkeeper's data of maximum in 2011 (Harlem River-Willis 
Table 4. Riverkeeper’s enterococcus data (MPN/100ml) [38].

\begin{tabular}{|c|c|c|c|c|c|}
\hline \multicolumn{2}{|c|}{ Date } & \multicolumn{2}{|l|}{ Willis Ave. Bridge } & Date & Washington Bridge \\
\hline \multicolumn{2}{|c|}{$7 / 7 / 14$} & \multicolumn{2}{|l|}{$<10$} & $7 / 7 / 14$ & 108 \\
\hline \multicolumn{2}{|c|}{$5 / 12 / 2014$} & \multicolumn{2}{|l|}{109} & $5 / 12 / 14$ & 148 \\
\hline \multicolumn{2}{|c|}{$8 / 14 / 13$} & \multicolumn{2}{|l|}{173} & $8 / 14 / 13$ & 1670 \\
\hline \multicolumn{2}{|c|}{$8 / 16 / 11$} & \multicolumn{2}{|l|}{565} & $10 / 10 / 12$ & 132 \\
\hline \multicolumn{2}{|c|}{$5 / 16 / 11$} & \multicolumn{2}{|l|}{448} & $5 / 16 / 11$ & 121 \\
\hline \multicolumn{2}{|c|}{$10 / 12 / 11$} & \multicolumn{2}{|l|}{487} & $10 / 12 / 10$ & 816 \\
\hline \multicolumn{2}{|c|}{$7 / 28 / 09$} & \multicolumn{2}{|l|}{399} & 7/14/08 & 231 \\
\hline \multicolumn{2}{|c|}{$6 / 5 / 09$} & \multicolumn{2}{|l|}{512} & 4/18/07 & 244 \\
\hline \multicolumn{2}{|c|}{$7 / 14 / 08$} & \multicolumn{2}{|l|}{5635} & $10 / 18 / 06$ & 1467 \\
\hline $6 / 24$ & & 160 & & 7/11/07 & 238 \\
\hline $4 / 18$ & & 356 & & 4/18/07 & 274 \\
\hline $11 / 10$ & & 310 & & & \\
\hline $10 / 18$ & & 263 & & & \\
\hline Date & North River WWTP & Date & Gowanus Canal & Date & Newtown Creek-Metropolitan Ave. Bridge \\
\hline $7 / 17 / 13$ & 723 & $8 / 14 / 13$ & 364 & $8 / 14 / 13$ & 4352 \\
\hline $10 / 10 / 12$ & 2098 & $11 / 8 / 12$ & $>24,196$ & $11 / 8 / 12$ & 1095 \\
\hline $9 / 10 / 13$ & 2987 & $10 / 10 / 12$ & 259 & $10 / 10 / 12$ & 446 \\
\hline $8 / 13 / 12$ & 521 & $7 / 16 / 12$ & 241 & $7 / 16 / 12$ & 414 \\
\hline $10 / 21 / 11$ & 794 & $5 / 16 / 11$ & $>24,196$ & $5 / 15 / 12$ & 146 \\
\hline $8 / 16 / 11$ & 201 & $10 / 10 / 10$ & $>24,196$ & $10 / 21 / 00$ & 2300 \\
\hline $6 / 27 / 11$ & 262 & $8 / 17 / 10$ & 4884 & 8/16/11 & 613 \\
\hline $7 / 14 / 08$ & 147 & $6 / 10 / 10$ & 882 & $5 / 16 / 11$ & 1063 \\
\hline $4 / 18 / 07$ & 236 & 6/19/09 & 160 & $10 / 12 / 10$ & $>24,196$ \\
\hline & & $5 / 29 / 09$ & 17,329 & 8/17/10 & 3873 \\
\hline & & $7 / 23 / 08$ & 5790 & $10 / 29 / 09$ & $>24,196$ \\
\hline & & $5 / 16 / 08$ & $>24,196$ & 6/22/09 & 880 \\
\hline & & & & 6/18/09 & $>24,196$ \\
\hline & & & & $6 / 5 / 09$ & 977 \\
\hline & & & & $9 / 26 / 08$ & $>24,196$ \\
\hline & & & & 8/19/08 & 223 \\
\hline & & & & 7/23/08 & $>24,196$ \\
\hline & & & & 7/14/08 & $>24,196$ \\
\hline & & & & $7 / 2 / 08$ & 159 \\
\hline & & & & $6 / 24 / 18$ & 268 \\
\hline
\end{tabular}

All the selected data >111 MPN, not acceptable, all under wet weather condition; WWTP: Waste Water Treatment Plant; data source: www.riverkeeper.org; http://www.riverkeeper.org/water-quality/locations/nyc-hudson-bergen/harlem-river-willis-ave-bridge/; http://www.riverkeeper.org/water-quality/locations/nyc-hudson-bergen/harlem-river-washington-bridge/; http://www.riverkeeper.org/water-quality/locations/nyc-hudson-bergen/north-river-stp/;

http://www.riverkeeper.org/water-quality/locations/nyc-hudson-bergen/gowanus-canal/;

http://www.riverkeeper.org/water-quality/locations/nyc-hudson-bergen/newtown-creek-metropolitan-ave-bridge/.

Ave. Bridge: 565 MPN/100ml; Washington Bridge: 121 MPN/100ml). Riverkeeper's data (Table 4) showed that North River WWTP's maximum of enterococcus was 2987 on 9/10/13; Gowanus Canal-maximum was $>24,196$ on 5/16/11, 10/10/11 and 5/16/08; Newtown Creek Metropolitan Ave. Bridge maximum— $\longrightarrow 24,196$ on 10/12/10, 6/18/09, 9/26/08, 7/23/08 and 7/14/08 [37] [38]. All these unacceptable conditions appeared on wet weather conditions indicated the CSOs discharged raw sewer during wet weather conditions and increased bacteria levels, which was potentially cause illness and harmful to public health. 


\subsection{Ammonia}

Ammonia concentrations increased significantly during heavy rainstorm especially from April to October when water temperature is warmer. Ammonia concentration reached $2.725 \mathrm{mg} / \mathrm{L}$ during tropical storm Arthur on July 2, 2014 as well as heavy rain storm on May 8, 2013; $2.555 \mathrm{mg} / \mathrm{L}$ and $2.536 \mathrm{mg} / \mathrm{L}$ during two storms on October 2013; $2.293 \mathrm{mg} / \mathrm{L}$ on a dry day on May 1, 2013; $2.273 \mathrm{mg} / \mathrm{L}$ during morning rain on June 5, 2014; $1.848 \mathrm{mg} / \mathrm{L}$ during heavy rainstorm on Nov 1, 2013 (Figure 2). In most of the data, ammonia concentrations were significantly exceeded EPA criteria for region 2 NYC water of $0.23 \mathrm{mg} / \mathrm{L}$ [34]. The average $\mathrm{NH}_{3}-\mathrm{N}$ (ammonia) concentration in 2013 data was $1.32 \mathrm{mg} / \mathrm{L}$, which was higher than average in 2012 (1.02 mg/L) and 2011 (0.831 $\mathrm{mg} / \mathrm{L})$. In 2012, before Hurricane Sandy on October 24, ammonia concentration was $0.516 \mathrm{mg} / \mathrm{L}$, increased to $0.653 \mathrm{mg} / \mathrm{L} 3$ days after Sandy on November 1 , and $0.665 \mathrm{mg} / \mathrm{L}$ one day after Nor'easter snowstorm on November 8, 2012 (Figure 3). CSOs during extreme super storm such as Sandy increased ammonia levels in the river. On April 28, 2011 during heavy thunderstorm, ammonia concentration was $1.449 \mathrm{mg} / \mathrm{L}$; the maximum ammonia in 2011 was 2.205 mg/L on July 132011 (Figure 4). On July 25, 2011, five days after North River WWTP raw sewage spill, ammonia was tested in the Harlem River and the Hudson River; ammonia in the Harlem River site 3a was $1.214 \mathrm{mg} / \mathrm{L}$ and 3c was $1.326 \mathrm{mg} / \mathrm{L}$ (Figure 4); which were around twice of ammonia in the Hudson River $(0.627 \mathrm{mg} / \mathrm{L})$. Results showed that ammonia increased significantly during rainstorms/tropical storms.

\subsection{Phosphate (SRP)}

Similar as ammonia, phosphate (ortho-phosphate or soluble reactive phosphorus-SRP) reached $0.181 \mathrm{mg} / \mathrm{L}$ that was the highest in 2013 during rain storm Oct $7^{\text {th }}$, followed by $0.176 \mathrm{mg} / \mathrm{L}$ during rain on Oct $4^{\text {th }}, 0.173 \mathrm{mg} / \mathrm{L}$ during rain storm on May 8, $0.172 \mathrm{mg} / \mathrm{L}$ on Nov $1^{\text {st }}$ during heavy rain storm (Figure 5); phosphate concentration reached $0.197 \mathrm{mg} / \mathrm{L}$ during tropical storm April 28, 2011 (Figure 6). Phosphate and ammonia (Figures 2-6) showed that ammonia and phosphates shared the same pattern that significantly increasing concentrations during heavy rains. In 2011, the peak concentration of SRP appeared during the heavy thunderstorm on April 28, 2011 in the CSOs of $0.197 \mathrm{mg} / \mathrm{L}$ (Figure 6). Average SRP in 2013 was $0.145 \mathrm{mg} / \mathrm{L}$ and is higher the SRP in 2011 of $0.102 \mathrm{mg} / \mathrm{L}$; which was more than (similar to) twice of SRP average in the Bronx River $(0.067 \mathrm{mg} / \mathrm{L}$ in 2006; $0.068 \mathrm{mg} / \mathrm{L}$ in 2007) [46] [47]. Phosphate level was largely above EPA standard of 0.033 mg/L [33], and P levels were increased significantly during storms. Ortho-phosphate concentrations were from 0.0001 to 0.0015

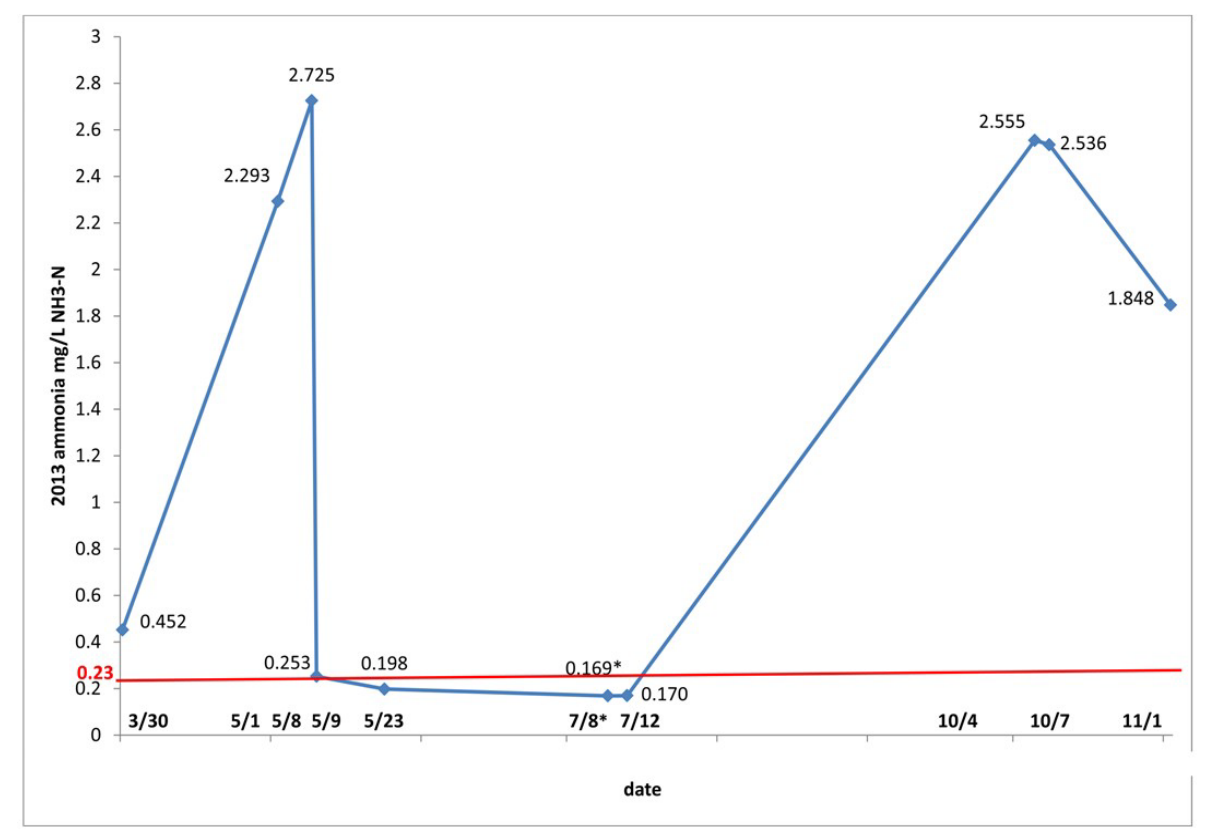

Figure 2. 2013 Ammonia in the Harlem River water. 2013: Water sampling at site 3a, other than * site at site 5 Randall's Island close to CSO discharge point. 


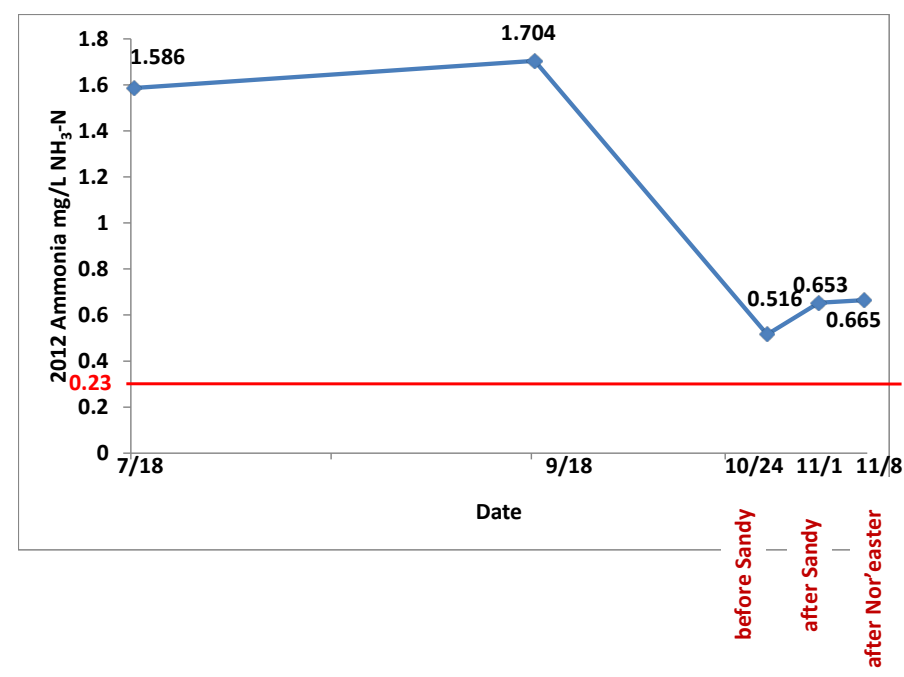

Figure 3. 2012 Ammonia in the Harlem River water. 2012: water sampling at site 3a.

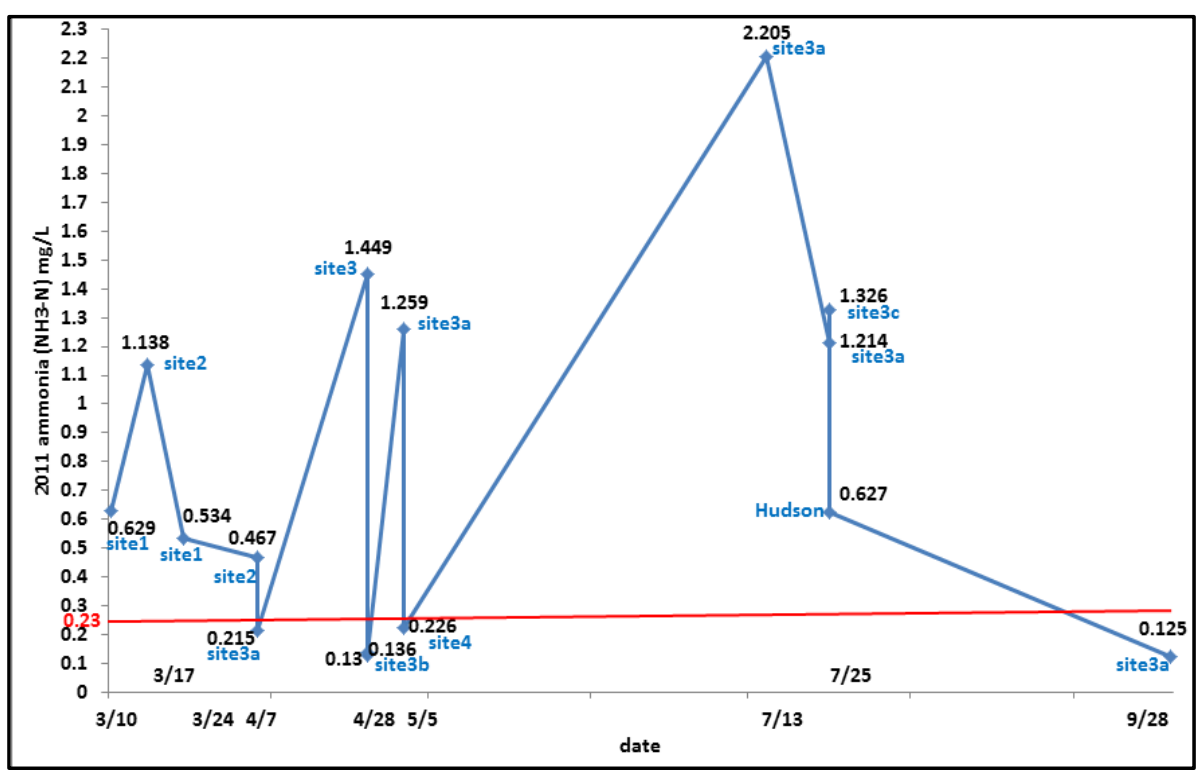

Figure 4. 2011 Ammonia in water samples collected from the Harlem River (water sampling on different sites). 2011: water sampling at sites 1, 2, 3, 3a, 3b, 3c, 4, and Hudson River North River WWTP raw sewer spill site.

mg/L (or 0.1 - $0.15 \mu \mathrm{g} / \mathrm{L}$ ) from USGS's 5-year seasonal data [28]; which were significantly lower than our data; therefore it is important to report and publish updated phosphate level in the Harlem River. Total P (TP) and organic P (OP) was tested on limited water samples collected in 2011; the TP maximum was $3.115 \mathrm{mg} / \mathrm{L}$ during April 28 heavy thunderstorm at CSO discharge point site 3, followed by 0.624 on March 17 at site 2, and 0.581 at site 4 on May 5; average TP was $0.531 \mathrm{mg} / \mathrm{L}$ which was higher than average TP in the Bronx River (0.438 $\mathrm{mg} / \mathrm{L}$ in 2006 and $0.089 \mathrm{mg} / \mathrm{L}$ in 2007) [46] [47]. Organic $P$ average was $0.428 \mathrm{mg} / \mathrm{L}$, which was higher than average OP in the Bronx River as well (0.372 mg/L in 2006; 0.021 mg/L in 2007) [46] [47]; OP maximum was $2.919 \mathrm{mg} / \mathrm{L}$ during heavy thunderstorm on April 28 2011. OP could potentially be hydrolyzed to SRP becoming bioavailable P (BAP), and the enzymatically hydrolysable P (EHP); which have impact on water quality [46]-[51]. Phosphorus (P) is a major nutrient for plant growth, and is a primary limiting nutrient in rivers and streams [50] [52]-[54]. Excessive P results in eutrophication of freshwater systems, in turn, excessive algal growth/toxic algal blooms, oxygen depletion, and water quality degradation [46]-[51] [55] [56]. 


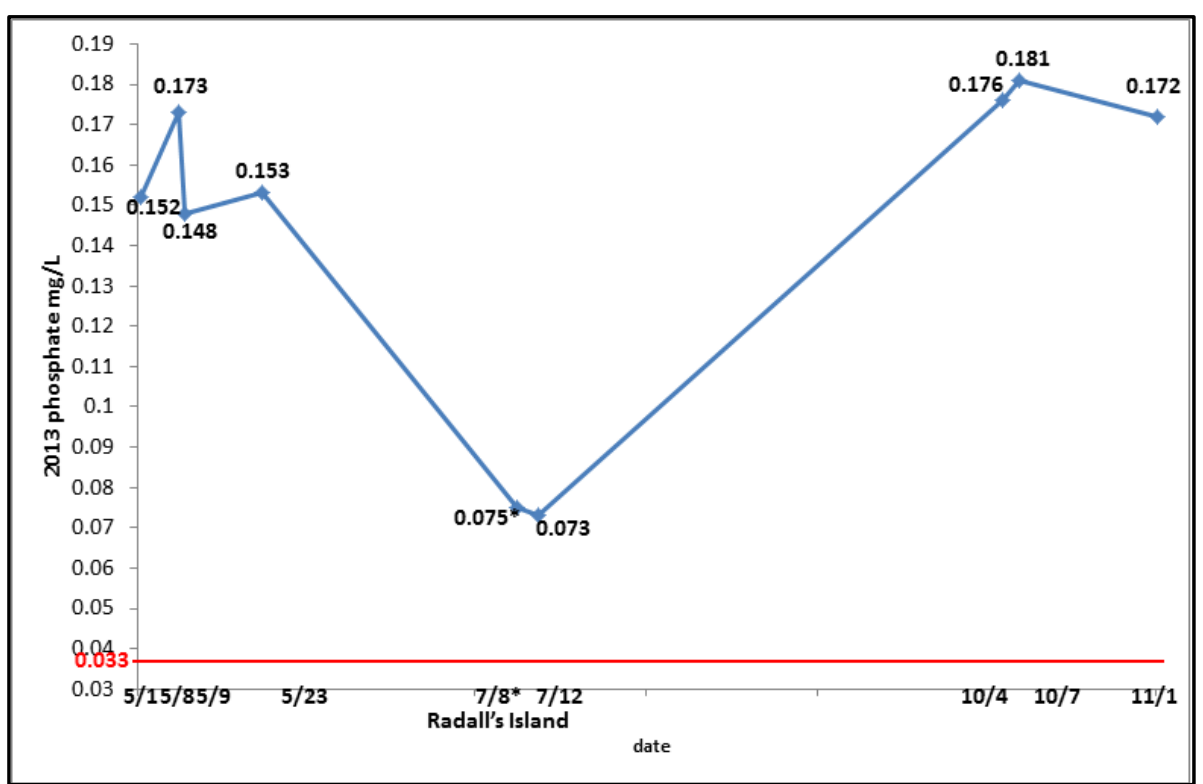

Figure 5. 2013 phosphate in water samples collected from the Harlem River. 2013: Water sampling at 3a, other than * site at site 5 Randall's Island close to CSO discharge point.

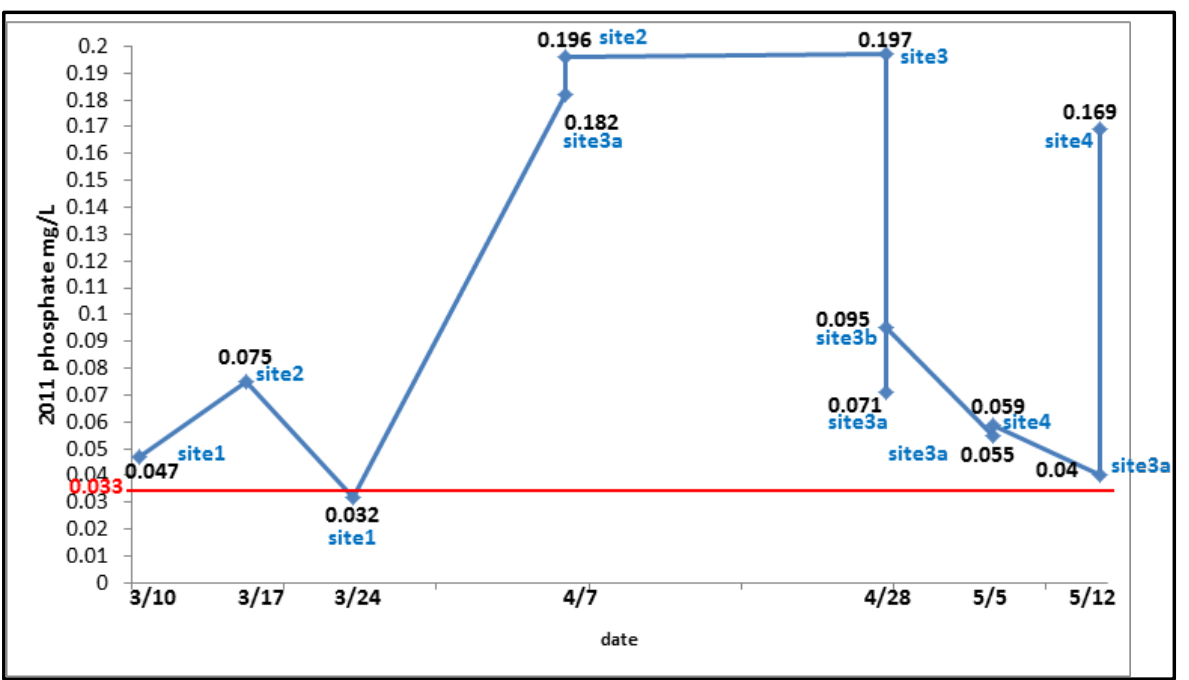

Figure 6. 2011 phosphate in water samples collected in the Harlem River. 2011: water sampling at sites 1, 2, 3, 3a, 3b, 3c, 4.

\subsection{Turbidity}

The turbidity in CSOs collected during tropical storm Arthur on July 22014 was 882 FAU, which was the maximum during data from 2011-2014. Results showed that CSOs during tropical storm Arthur increased nutrients (ammonia), bacteria and turbidity significantly. Turbidity was 112 FAU during heavy rainstorm on April 30, 2014. In 2013, turbidity was highest of 107 FAU during the showers on July 12 (Figure 7). The dilution factors could decrease turbidity during and after rainstorm. In 2012, turbidity increased from 4 FAU to 48 FAU after Hurricane Sandy (Figure 8). Rainstorm and Hurricane Sandy stirred the water increasing turbidity in the Harlem River. In 2011, turbidity peaked at the heavy thunderstorm on April 28, 2011 of 245 FAU (Figure 9), and at site 4 where the waters were muddy of 232 FAU on a sunny day; which were higher than Riverkeeper's data maximum (9/14/2011) of 198 FAU at Willis Ave. Bridge and 183 FAU at Washington Bridge [37] [38]. Turbidity also could be affect by surrounding suspended sediment environment, such as the muddy sediments at 


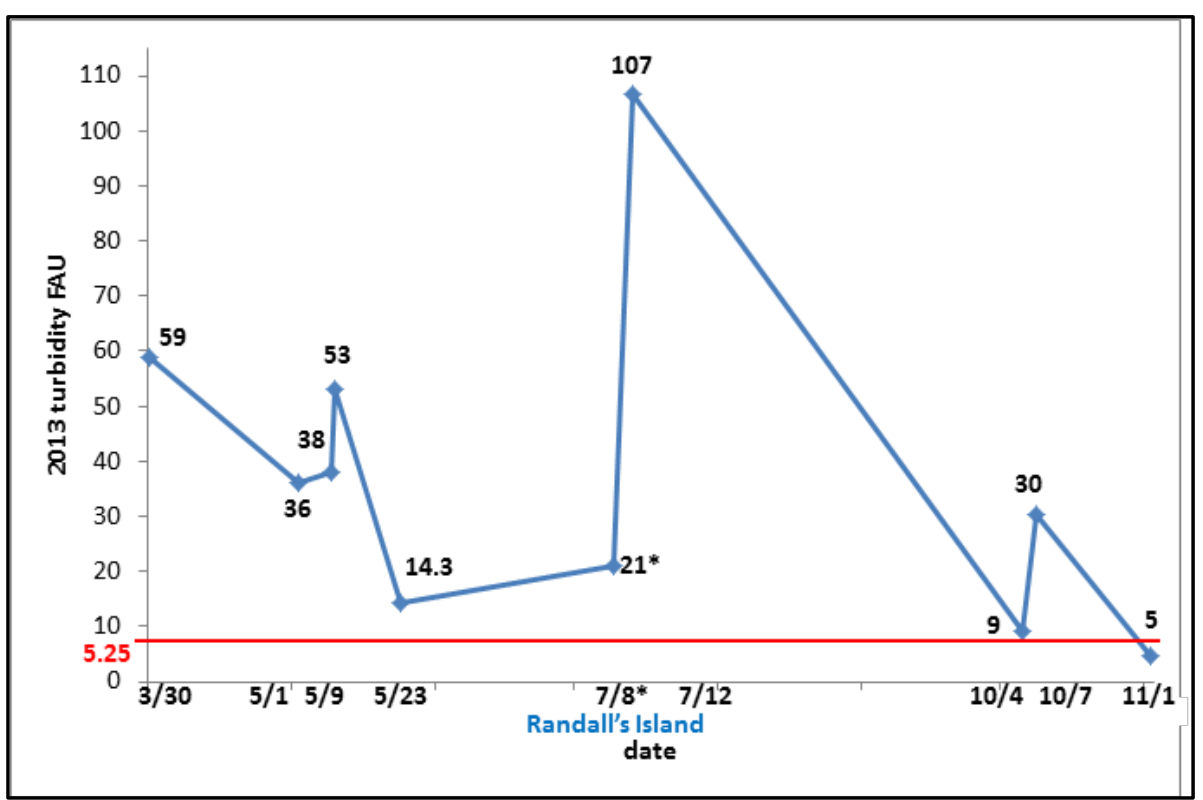

Figure 7. 2013 turbidity in water samples collected from the Harlem River. 2013: water sampling at site 3a, other than 7/8/12 site at site 5 Randall's Island close to CSO discharge point.

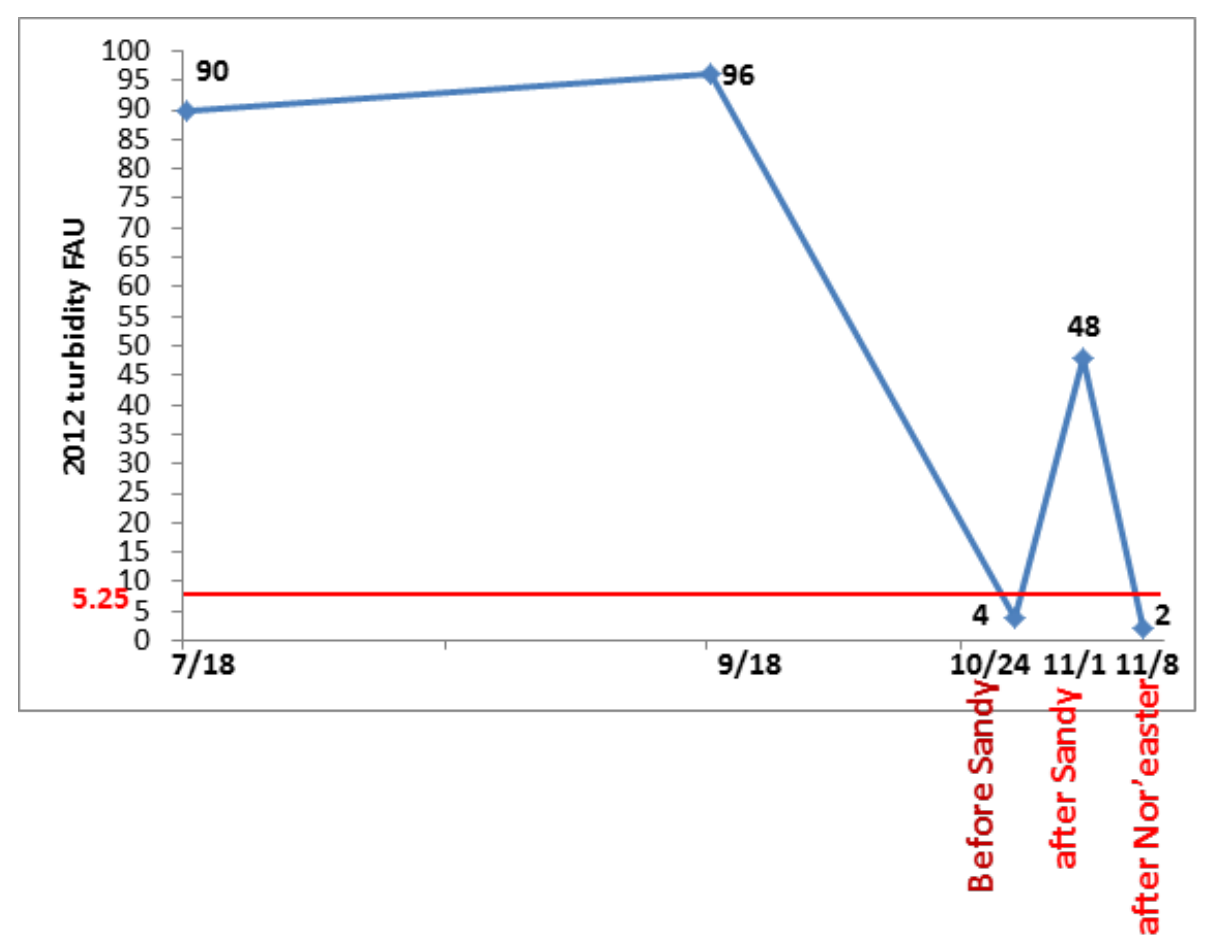

Figure 8. 2012 turbidity in water samples collected from the Harlem River. 2012: water sampling at site 3a.

site 4. Overall turbidity levels (Figures 7-9) were significantly higher than EPA standard: 0.25 - 5.25 FAU [33] [36]. On the heavy rainstorm on April 28, 2011, ammonia, phosphate, turbidity, E.Coli and fecal coliform reached the highest level during the year of 2011; however, no enterococcus found during that storm that is uncommon. 


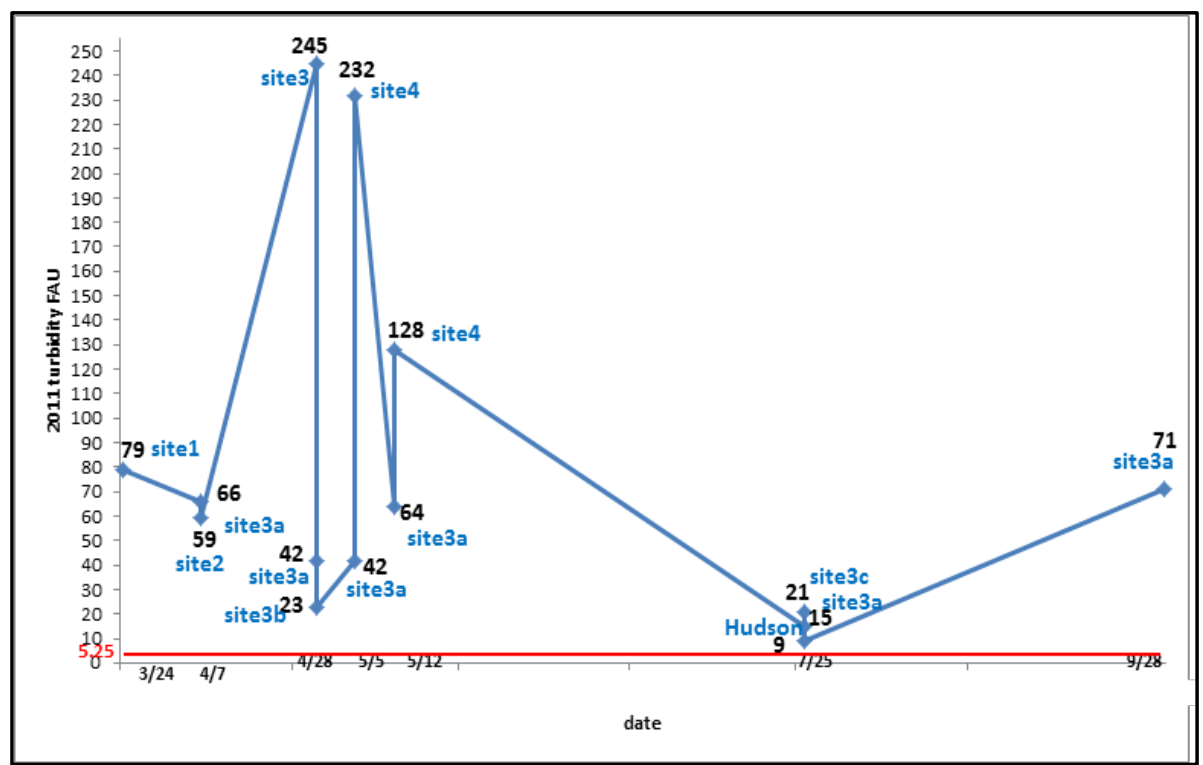

Figure 9. 2011 Turbidity in water samples collected from the Harlem River. 2011: water sampling at sites 1, 2, 3, 3a, 3b, 3c, 4, and Hudson River North River WWTP raw sewage spill site.

\subsection{PCBs}

3,3'-Dichlorobiphenyl (BZ\#11) was the primary interest of the PCB analysis. The peak from GC/MS analysis in concentrated water samples appeared to be PCB 11. Spiked water sample showed the same peaks of 3,3'-dichlorobiphenyl. However, further experimental analysis was needed. From the results, there are different chemicals found in river water samples, such as 1,1-dibromodifluoroethylene, acetic acid, (3,4-dichlorophenoxy). The concentrations of PCBs in river waters usually considered as low, not easy to detect and could below detect limit. Spiking technique had been used on this research. PCBs concentrations in the Harlem River were below the detection limits. It is ongoing to try other techniques for PCBs identification.

\subsection{Reduce CSOs}

Wetland can be constructed to capture storm water, and remove pollutants from storm water runoff (Harlem River renaissance, 2014). Green infrastructure such as green walls, green corridor could be built for storm water retention and treatment [57]. An ultra-light weight green roof plant growth medium, which has higher adsorption than regular soil, has been used as a biogeochemical reactor to breakdown dioxins and PCBs [58]. Meanwhile, wetland and green infrastructure could help improve the waterfront access, improve the community activity along the river [59]. Green roof and green wall have been built in the Bronx to help storm water capture; storm water treatment and CSO reduction on the Bronx River [58]. The bio-composting system has been used on green roof in Manhattan to reduce storm water runoff and CSOs [60].

\section{Future Perspective of the Research}

If funding is available, water quality parameters will be tested in more locations from Spuyten Duyvil-Metro North Hudson line station where the Hudson River joins to its tributary, to Wards Island where the Harlem River joins to the East River. Spatial and temporal variations will be analyzed. DO will be tested for each water sample collection continuously. PCBs analysis is on-going. There is no guarantee to detect any PCB above detection limits in water samples; however PCBs identification is possible with different techniques. Water samples will be further concentrated for non-Aroclor congener PCB 11 and Aroclor 1242/1254 analysis, and spiking techniques will be used. Sediment samples will be collected for nutrients and PCBs analysis. Undergraduate students from BCC and Lehman College, CUNY will be involved in this water quality research as part of environmental science courses. 


\section{Conclusion}

This research analyzed impact of CSOs on water quality as well as environmental ecosystem and public health in the Harlem River. Phosphate, ammonia, fecal coliform, E.Coli enterococcus levels increased during rainstorms. Enterococcus levels were higher than Riverkeeper's record. Ammonia maximum was $2.725 \mathrm{mg} / \mathrm{L}$, and far exceeded EPA level of $0.23 \mathrm{mg} / \mathrm{L}$; phosphate maximum was $0.196 \mathrm{mg} / \mathrm{L}$ significantly higher than EPA standard which is $0.033 \mathrm{mg} / \mathrm{L}$; turbidity maximum was $245 \mathrm{FAU}$ in 2011, almost 50 times that of EPA standard of 0.25 - 5.25 FAU. Fecal coliform, E.Coli, and enterococcus exceeded EPA regulated levels (200, 126, 104 MPN/100ml). Nutrients and bacteria levels were significantly higher than USGS data record. Turbidity and enterococcus data showed higher levels compared to Riverkeeper's data. PCBs (PCB 11) were below detection limit, and future analysis was expected. CSOs discharge in the Harlem River during rainstorms increased nutrient and bacteria levels, degraded water quality, threatened fish consumption safety, which is a critical issue in NYC waters. It is hoped that any solution could help improve water quality, and make the Harlem River swimmable and fishable again in the future.

\section{References}

[1] Even, S., Mouchel, J., Servais, P., Flipo, N., Poulin, M., Blanc, S., Chabanel, M. and Paffoni, C. (2007) Modelling the Impacts of Combined Sewer Overflows on the River Seine Water Quality. Science of the Total Environment, 375, 140-151.

[2] US EPA (2001) Source Water Protection Practices Bulletin. Managing Sanitary Sewer Overflows and Combined Sewer Overflows to Prevent Contamination of Drinking Water. EPA 916-F-01-032.

http://www.epa.gov/safewater/sourcewater/pubs/fs_swpp_ssocso.pdf

[3] Diaz-Fierros, T.F., Puerta, J., Suarez, J. and Diaz-Fierros, V.F. (2002) Contaminant Loads of CSOs at the Wastewater Treatment Plant of a City in NW Spain. Urban Water, 4, 291-299.

[4] Passerat, J., Ouattara, N.K., Mouchel, J., Rocher, V. and Servais, P. (2011) Impact of an Intense Combined Sewer Overflow Event on the Microbiological Water Quality of the Seine River. Water Research, 45, 893-903.

[5] US EPA (2011) FY 2011 National Water Program Guidance (NWPG). Office of Water Fiscal Year 2011. http://water.epa.gov/grants_funding/cwf/upload/nwp_program_guidance508_050510.pdf

[6] Boet, P., Duvoux, B., Allardi, J. and Billiard, J. (1994) Incidence des oragesestivaussur le peruplementpiscicole de la seine a l'aval de l'agglomerationparisenne (biefandresy-mericourt). La HouilleBalanche, 1/2, 141-147.

[7] Gasperi, J., Garnaud, S., Rocher, V. and Moilleron, R. (2008) Priority Pollutants in Wastewater and Combined Sewer Overflow. Science of the Total Environment, 407, 263-272.

[8] Varlero, M.A.C., Johanson, M. and Mara, D.D. (2007) Enhanced Phosphorus Removal in a Waste Stabilization Pond System with Blast Furnace Slag Filters. Desalination and Water Treatment, 4, 122-127.

[9] Chen, X., Chen, X., Wan, X., Weng, B. and Huang, Q. (2010) Water Hyacinth (Eichhorniacrassipes) Waste as an Adsorbent for Phosphorus Removal from Swine Wastewater. Bioresource Technology, 101, 9025-9030.

[10] Dubrovsky, N.M. and Hamilton, P.A. (2010) Nutrients in the Nation's Streams and Groundwater: National Findings and Implications: US Geological Survey Fact Sheet 2010-3078. http://pubs.usgs.gov/fs/2010/3078/

[11] US EPA (2007) National Estuary Program Coastal Condition Report. Chapter 3: Northeast National Estuary Program. Coastal Condition, New York/New Jersey Harbor Estuary Program, 131-141. http://water.epa.gov/type/oceb/nep/upload/2007_05_09_oceans_nepccr_pdf_nepccr_nepccr_ne_parti.pdf

[12] amNew York (2011) 2011 Section 04 Earth Day: Water. http://www.amny.com/

[13] Itasaka, N., Takanashi, H., Hirata, M. and Hano, T. (1999) Development of Adsorbents for Removal and Recovery of Phosphorus in Low Concentration from Wastewater. Journal of Water and Waste, 41, 195-203. (in Japanese)

[14] Hu, W. (2013) Helping the Bronx River by Giving Oysters a New Home. The New York Times. http://www.nytimes.com/2013/09/24/nyregion/in-bronx-river-helping-oysters-stage-comeback.html

[15] Bopp, R.F. (1979) The Geochemistry of Polychlorinated Biphenyls s in the Hudson River. Ph.D. Thesis, Columbia University, New York.

[16] Pataki, G.E. and Crotty, E.M. (2002) Hudson River Estuary Action Plan 2001. New York State Department of Environmental Conservation, The Hudson River Estuary Program. http://www.dec.ny.gov/docs/remediation_hudson_pdf/actionplan2001.pdf

[17] Riverkeeper (2013) Hudson River PCBs. http://www.riverkeeper.org/campaigns/stop-polluters/pcbs/

[18] Rodenburg, L.A., Du, S., Xiao, B. and Fennell, D.E. (2011) Source Apportionment of Polychlorinated Bipheyls in the New York/New Jersey Harbor. Chemosphere, 83, 792-798. http://dx.doi.org/10.1016/j.chemosphere.2011.02.058 
[19] Rodenburg, L.A., Guo, J., Du, S. and Cavallo, G.J. (2010) Evidence for Unique and Ubiquitous Environmental Sources of 3,3’-Dichlorobiphenyl (PCB11). Environmental Science and Technology, 44, 2816-2821. http://dx.doi.org/10.1021/es901155h

[20] Totten, L.A. (2005) Present-Day Sources and Sinks for Polychlorinated Biphenyls (PCBs) in the Lower Hudson River Estuary. In: Panero, M., Boehme, S. and Munoz, G., Eds., Pollution Prevention and Management Strategies for Polychlorinated Biphenyls in the New York/New Jersey Harbor, New York Academy of Sciences, New York.

[21] US EPA (1999) Hudson River PCBs, PCBs and Human Health. http://www.epa.gov/hudson/humanhealth.htm

[22] Chillrud, S.N. (1996) Transport and Fate of Particle Associated Contaminants in the Hudson River Basin. Ph.D. Thesis, Columbia University, New York.

[23] The Hudson River Dredging Project (2013).

[24] US EPA (2013) Hudson River Cleanup. http://www.epa.gov/hudson/cleanup.html

[25] New York State Department of Health (NYS DOH) (2013) New York City Region Fish Advisories. http://www.health.ny.gov/environmental/outdoors/fish/health_advisories/regional/new_york_city.htm

[26] New York State Department of Health (NYS DOH) (2011) Information for a Healthy New York. New York City: Health Advice on Eating Fish You Can Catch, 2010-2011. http://www.health.ny.gov/publications/2784/index.htm

[27] Wagner, R.F. (2009) South Bronx Environmental Health and Policy Study, Water Quality in the South Bronx Watershed. Institute for Civil Infrastructure Systems. Graduate School of Public Service, New York University, New York. http://www.icisnyu.org/south_bronx/WaterQuality_001.html

[28] USGS (2012) Science for a Changing World. Prepared in Cooperation with US National Park Service, New York City Department of Environmental Protection. Urban Waters Initiative-Bronx \& Harlem Rivers. http://ny.cf.er.usgs.gov/nyprojectsearch/projects/images/2012HarlemRiver conference USGS.pdf

[29] Bronx Council for Environmental Quality (BCEQ) (2008) Reclaiming the Harlem River Waterfront. Envisioning a Better Future for the Bronx and the Harlem River with the Harlem River Working Group. http://www.bceq.org/wp-content/uploads/2008/02/HRWG-Complete-Presentation.pdf

[30] New York City Department of Environmental Protection (NYC DEP) (2002) Final Supplemental Environmental Impact Statement for the Croton Water Treatment Plant at the Harlem River Site. NYCDEP Marine Science Section. http://www.nyc.gov/html/dep/pdf/croton/7-15waterresources.pdf

[31] Phillip, N. (2010) Environmental Science-ENV 11 Laboratory Manual. Chemistry Department, Bronx Community College, City University of New York, New York.

[32] National Research Council (NRC), New York City Department of Environmental Protection (NYC DEP) (2006) Reducing Harmful Phosphorus Pollution in the New York City Reservoirs through the Clean Water Act's "Total Maximum Daily Load” Requirements: A Case Study of the New Croton Reservoir and Recommendation to EPA. http://www.ag.ny.gov/sites/default/files/pdfs/bureaus/environmental/phosphorus_report.pdf

[33] US EPA (2000) Ambient Water Quality Criteria Recommendations. Information Supporting the Development. Office of Water 4304. EPA 822-B-00-018.

http://water.epa.gov/scitech/swguidance/standards/criteria/nutrients/upload/2007_09_27_criteria_nutrient_ecoregions_r ivers_rivers_7.pdf

[34] New York State Department of Environmental Conservation (NYS DEC) (2006) Description of Proposed Action for 2006 Revision to 6NYCRR Part 700-704. In: Final Amendments to Water Quality Standards Regulations, 6 NYCRR Parts 700-704. Background Regarding Proposed Amendments to Water Quality Standards Regulations. Compendum of Water Quality Standards Rule Making Documents. http://www.dec.ny.gov/docs/water_pdf/propwqsreg.pdf

[35] US EPA (2012) Recreational Water Quality Criteria. Office of Water 820-F-12-058. http://water.epa.gov/scitech/swguidance/standards/criteria/health/recreation/upload/RWQC2012.pdf

[36] NYS DEC (2014) Part 703: Surface Water and Groundwater Quality Standards and Groundwater Effluent Limitations. http://www.dec.ny.gov/regs/4590.html\#16132

[37] Riverkeeper (NY’s Clean Water Advocate) (2013) Water Quality Testing Locations, New York City, Harlem RiverWillis Ave. Bridge; Harlem River-Washington Bridge. http://www.riverkeeper.org/water-quality/locations/nyc-hudson-bergen/harlem-river-willis-ave-bridge/ http://www.riverkeeper.org/water-quality/locations/nyc-hudson-bergen/harlem-river-washington-bridge/

[38] Riverkeeper (NY’s Clean Water Advocate) (2014) Water Quality Testing Locations, New York City, Harlem RiverWillis Ave. Bridge; Harlem River-Washington Bridge. http://www.riverkeeper.org/water-quality/hudson-river/nyc-hudson-bergen/harlem-river-willis-ave-bridge/ http://www.riverkeeper.org/water-quality/hudson-river/nyc-hudson-bergen/harlem-river-washington-bridge/

[39] Foderaro, L.W. (2013) Harlem River, Cut off from Public, Is Getting a Push Out of Isolation. The New York Times. http://www.nytimes.com/2013/10/23/nyregion/harlem-river-cut-off-from-public-is-getting-a-push-out-of-isolation.html 
[40] Wikipedia (2010) Harlem River. Final Supplemental Environmental Impact Statement for the Croton Water Treatment Plant at the Harlem River Site. http://en.wikipedia.org/wiki/Harlem_RiverMain Wikipedia (2014) Geography and Environment of New York City Geography of New York City. http://en.wikipedia.org/wiki/Geography_and_environment_of_New_York_City

[41] Hu, W. (2014) In South Bronx, Visions of a Bustling Shoreline. The New York Times. http://www.nytimes.com/2014/03/08/nyregion/in-the-south-bronx-a-plan-is-unveiled-to-develop-its-waterfront.html?re $\underline{\mathrm{f}=\text { todayspaper }}$

[42] Phillip, N. (2008) Environmental Science-ENV 11 Laboratory Manual. Department of Chemistry, Bronx Community College of City University of New York Department of Chemistry.

[43] US EPA (US Environmental Protection Agency) (1992) ESS Method 310.1: Ortho-Phosphorus, Dissolved Automated, Ascorbic Acid. Environmental Sciences Section Inorganic Chemistry Unit, Wisconsin State Lab of Hygiene, Madison. http://www.epa.gov/grtlakes/lmmb/methods/methd310.pdf

[44] US EPA (2007) Method 8082A. Polychlorinated Biphenyls (PCBs) by Gas Chromatography. Revision 1. http://www.epa.gov/osw/hazard/testmethods/sw846/pdfs/8082a.pdf

[45] Eganhouse, R.P. and Sherblom, P.M. (2001) Anthropogenic Organic Contaminants in the Effluent of a Combined Sewer Overflow: Impact on Boston Harbor. Marine Environmental Research, 51, 51-74. http://dx.doi.org/10.1016/S0141-1136(00)00035-0

[46] Wang, J. and Pant, H.K. (2012) Estimation of Phosphorus Bioavailability in the Water Columns of the Bronx River. Journal of Environmental Protection, 3, 316-323 http://www.scirp.org/journal/jep/ http://dx.doi.org/10.4236/jep.2012.34040

[47] Wang, J. and Pant, H.K. (2011) Land Use Impact on Bioavailable Phosphorus in the Bronx River, New York. Journal of Environmental Protection, 2, 342-358. http://www.SciRP.org/journal/jep http://dx.doi.org/10.4236/jep.2011.24038

[48] Wang, J. and Pant, H.K. (2011) Assessments of Potential Spatial-Temporal Variations in Phosphorus Distribution and Fractionation in River Bed Sediments. Clean-Soil, Air, Water, 39, 148-156. http://onlinelibrary.wiley.com/doi/10.1002/clen.201000088/pdf http://dx.doi.org/10.1002/clen.201000088

[49] Wang, J. and Pant, H.K. (2010) Phosphorus Sorption Characteristics of the Bronx River Bed Sediments. Chemical Speciation and Bioavailability, 22, 171-181. http://tinyurl.com/32cdd64 http://dx.doi.org/10.3184/095422910X12827492153851

[50] Wang, J. and Pant, H.K. (2010) Enzymatic Hydrolysis of Organic Phosphorus in River Bed Sediments. Ecological Engineering, 36, 963-968. http://dx.doi.org/10.1016/j.ecoleng.2010.03.006

[51] Wang, J. and Pant, H.K. (2010) Identification of Organic Phosphorus Compounds in the Bronx River Bed Sediments by Phosphorus-31 Nuclear Magnetic Resonance Spectroscopy. Environmental Monitoring and Assessment, 171, 309319. http://www.springerlink.com/content/e6t72u36676gxj06/ http://dx.doi.org/10.1007/s10661-009-1280-3

[52] Ahlgern, J., Tranvik, L., Gogoll, A., Waldeback, M., Markides, K. and Rydin, E. (2005) Sediment Depth Attenuation of Biogenic Phosporus Compounds Measured by ${ }^{31} \mathrm{P}$ NMR. Environmental Science and Technology, 39, 867-872. http://dx.doi.org/10.1021/es049590h

[53] Zhang, R.Y., Wu, F.C., Liu, C.Q., Fu, P.Q., Li, W., Wang, L.Y., Liao, H.Q. and Guo, J.Y. (2008) Characteristics of Organic Phosphorus Fractions in Different Trophic Sediments of Lakes from the Middle and Lower Reaches of Yangtze River Region and Southwestern Plateau, China. Environmental Pollution, 152, 366-372. http://dx.doi.org/10.1016/j.envpol.2007.06.024

[54] Neal, C., Jarvie, H.P., Williams, R.J., Neal, M., Wickham, H. and Hill, L. (2002) Phosphorus-Calcium Carbonate Saturation Relationships in a Lowland Chalk River Impacted by Sewage Inputs and Phosphorus Remediation: An Assessment of Phosphorus Self-Cleaning Mechanisms in Natural Waters. Science of the Total Environment, 282-283, 295310. http://dx.doi.org/10.1016/S0048-9697(01)00920-2

[55] Edwards, A.C. and Withers, P.J.A. (1998) Soil Phosphorus Management and Water Quality: A UK Perspective. Soil Use and Management, 14, 124-130.

[56] Correll, D.J. (1999) Phosphorus: A Rate Limiting Nutrient in Surface Waters. Poultry Science, 78, 674-682. http://dx.doi.org/10.1093/ps/78.5.674

[57] The Gala Institute (2014) http://thegaiainstitute.org/

[58] Mankiewicz, P. (2010) http://tedxkrakow.com/en/videos/14-paul-mankiewicz-integrating-ecosystems-with-urban-and-industrial-landscapes

[59] Harlemriverrenaissance (2014) http://harlemriverworkinggroup.org/

[60] Mankiewicz, P. (2013) http://vimeo.com/groups/focusforwardfilms/videos/51886928 
Scientific Research Publishing (SCIRP) is one of the largest Open Access journal publishers. It is currently publishing more than 200 open access, online, peer-reviewed journals covering a wide range of academic disciplines. SCIRP serves the worldwide academic communities and contributes to the progress and application of science with its publication.

Other selected journals from SCIRP are listed as below. Submit your manuscript to us via either submit@scirp.org or Online Submission Portal.
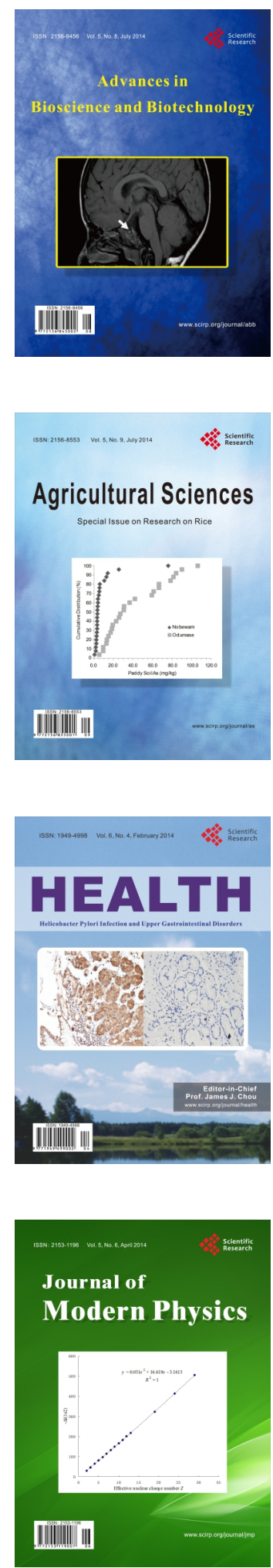
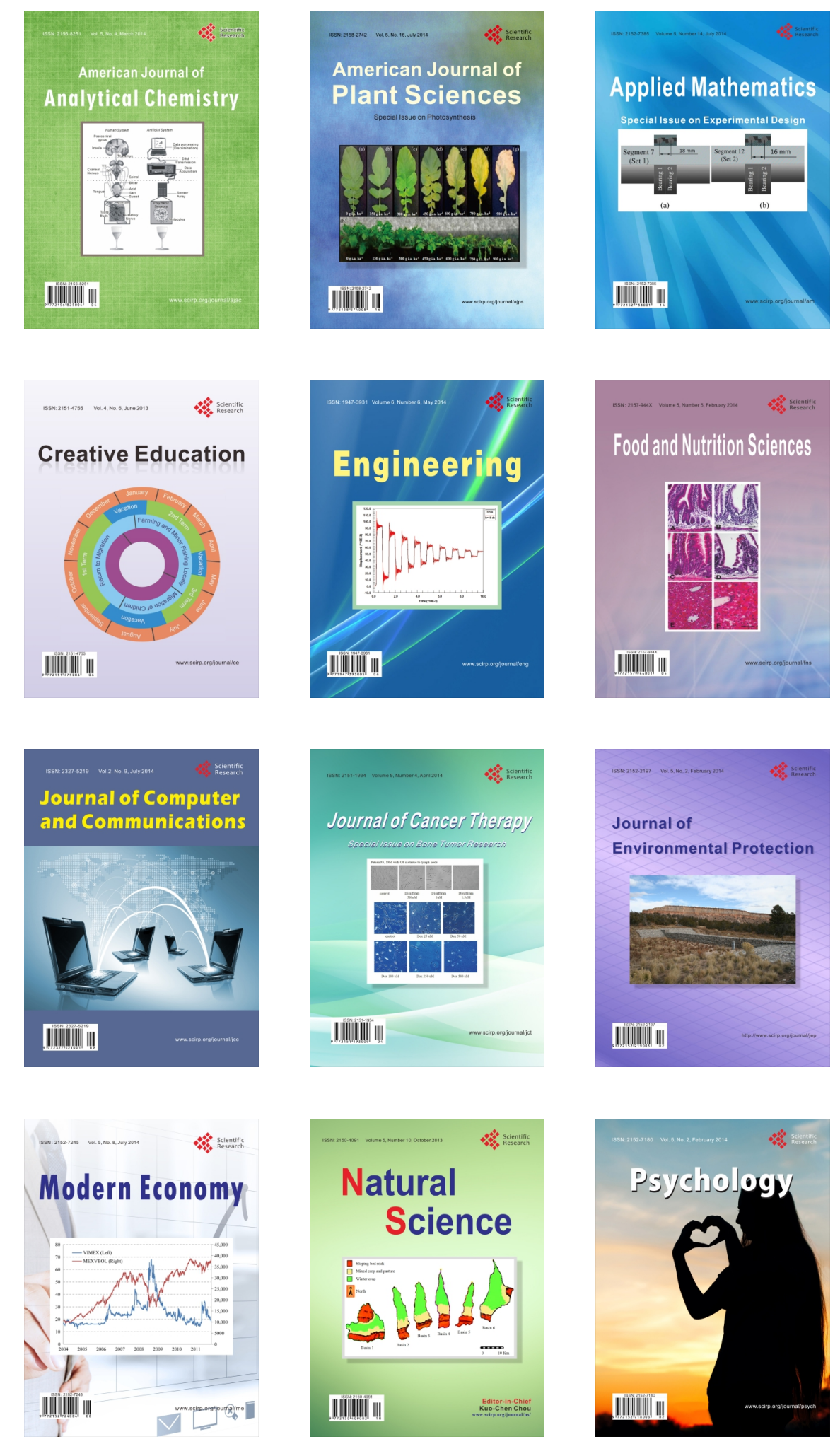